\title{
大学新入生のソーシャルスキルとソーシャルサポートが 心理的ストレス反応に及ぼす影響
}

\author{
○五十川ちよみ ${ }^{1} \quad$ 野村和孝 $^{1} \quad$ 丹波秀夫 ${ }^{2} \quad$ 嶋田洋徳 $^{3}$ \\ ( ${ }^{1}$ 早稲田大学大学院人間科学研究科 .2 早稲田大学大学院文学研究科. ${ }^{3}$ 早稲田大学人間科学学術院) \\ Key words ：ソーシャルスキル・ソーシャルサポート・心理的ストレス反応
}

\section{【問題と目的】}

今日の心理的ストレス研究では，ソーシャルスキル（以下 スキル）やソーシャルサポート（以下サポート）といった， ストレスモデルの構成要因に対し直接的・間接的に影響を与 えると考えられる環境的・個人的資源が，どのような役割を 果たしているかに注目が集まっている(岡安・嶋田・坂 野,1993: 嶋田・戸ヶ崎・岡安・坂野,1996: 橋本,2000など)。

五十川ら（2006）は，大学新入生のスキルと期待されたサ ポートの関連について継時的に検討を行い, スキルの高い者 はサポートが高く，また，スキルの高低にかかわらず時間経 過に伴いサポート期待が高まることを明らかにした。

また, Isogawa et al. (In Press) は, ストレス緩衝効果 の継時的な変化と, サポートの質的側面（サポートの機能） および量的側面 (友人の数) との関連について検討を行った。 その結果，ストレス緩衝効果を持つサポート機能は時期によ って異なること, また, 友人数の多少は緩衝効果の大きさに 影響しないことが示唆され, 状況に適したサポートを提供し てくれる者が少数でも存在することが, 大学新入生のストレ スの低減に有効である可能性が示された。

そこで, 本研究では, それらの研究の結果をふまえ, 入学 直後のスキルの高低および友人の数の多少が，心理的ストレ ス反応の及ぼす影響について，サポートの機能的側面から継 時的に検討することを目的とする。

\section{【方 法】}

分析対象: 都内私立大学に在籍する大学新入生 121 名（男性 60 名, 女性 61 名, 平均年齢 $19.0 \pm 1.1$ 歳 ）

調査方法：5月上旬と 7 月下旬に質問紙による調査を行った。 測度：(1)対人ストレッサー尺度（橋本,1997）(2)スキル尺度 （KiSS-18 ; 菊池, 1988) (3)サポート尺度（福岡,2000）を 参考に, 各サポートを提供してくれる友人が何人いるかを回 答させた。サポートは 1 ) 助言・相談，2）慰め・励まし, 3 ）物質的 - 金銭的援助, 4) 行動的援助の下位尺度で構成 される。(4)ストレス反応尺度(SRS-18 ; 鈴木ら，1998)。

\section{【結果と考察】}

ソーシャルスキル尺度得点に基づき, 平均值以上の者をス キル高 (Sk 高) 群, 平均值未満の者をスキル低 ( Sk 低) 群 として群分けした。また, ソーシャルサポート尺度の得点に 基づき, サポートなし (Sp なし) 群, サポート少 ( $\mathrm{Sp}$ 少) 群, サポート多 (Sp 多) 群の 3 群に群分けした。ソーシャ ルスキルの群とソーシャルサポートの群の組み合わせによ

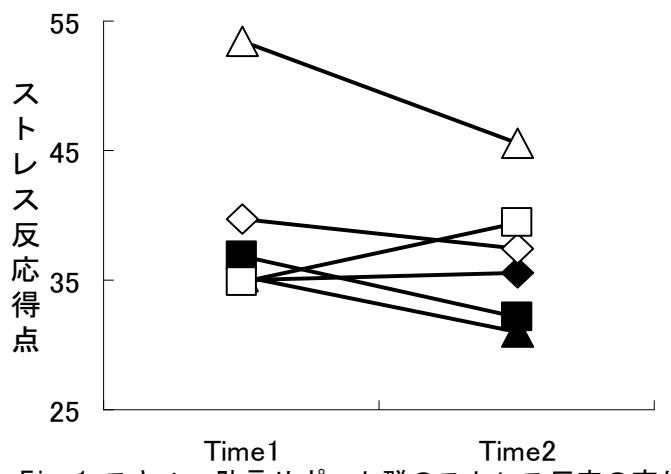

Fig 1:スキル×助言サポート群のストレス反応の変化
り計 6 群を設定し, 時期 2 (Time1,Time2) ×群 6 (前述)を独 立変数, 対人ストレッサーを共変量, ストレス反応を従属 変数とした 2 元配置分散分析を, サポート機能ごとに行った。 助言サポート: Sk 低 Sp なし群が最もストレス反応が低いこ とが示され, Sk 低群であっても Sp なし群は Sp 低群に比べ ストレス反応が高いこと $(F[5,86]=1.66 p<.05)$ が示された。

(Fig.1) これは Time1 から Time2 にかけても変化はなく, スキルが低い者は少数でも助言サポートとして機能する友 人を持つことで，ストレス反応が低減する可能性が示された。 慰めサポート: Sk 高 Sp 少群が最もストレス反応が低く, $\mathrm{Sk}$ 低 $\mathrm{Sp}$ なし群が最もストレス反応が高かった。同じ $\mathrm{Sk}$ 高 群において, Sp 少群に比べ $\mathrm{Sp}$ 多群の方が, 有意にストレス 反応が高いこと（F[5,86]=1.70 $p<.05 ）$ が示された。（Fig.2） また, 統計的有意差はないものの, Sk 低群においても Sp 少 群は時間経過に伴いストレス反応の平均值が減少し, Sp 多 群は平均值が増加している。これより, 情緒的なサポートを 提供してくれる友人が多すぎることは，互恵性の問題などか ら逆にストレッサーともなり得るため, 個人のストレス反応 を増加させる可能性が示された。

物理的サポート: Sk 高 Sp 少群が最もストレス反応が低く, 同じ $\mathrm{Sp}$ 低群でも Sk 高群に比べ, Sk 低群の方が有意にスト ス反応が高いこと（ $F[5,86]=1.90 p<.05 ）$ が示された。これ より, 物理的サポートは単にサポート源の存在だけでなく, 機能させるためのスキルも必要である可能性が示された。

行動的サポート: いずれも有意な差は見られなかった。これ より，行動的サポートはストレス反応の低減には影響しない 可能性が示された。

各群内の時間に伴う変化は, 全てのサポート, 群において 有意ではなかった。これは, 群内の分散の大きさによるもの であると考えられ，今後サンプル数を増やす，より長期的な 検討を行うなどの改善が望まれる。

\section{【総合考察】}

本研究より, 単純にサポートが多ければ多いほじ望ましい というわけではなく, 個人のスキルと期待できるサポートの 適合が重要である可能性が示された。大学新入生においては, スキルの低い者には, 少数でも助言サポートを提供してくれ る友人を弁別し関係を作ることが, また, 物理的サポートが 期待できる場合は，サポート希求スキルを身につけることが, ストレス反応の低減につながることが予想され，行動的な介 入のターゲットを設定する上で有用な示唆が得られた。
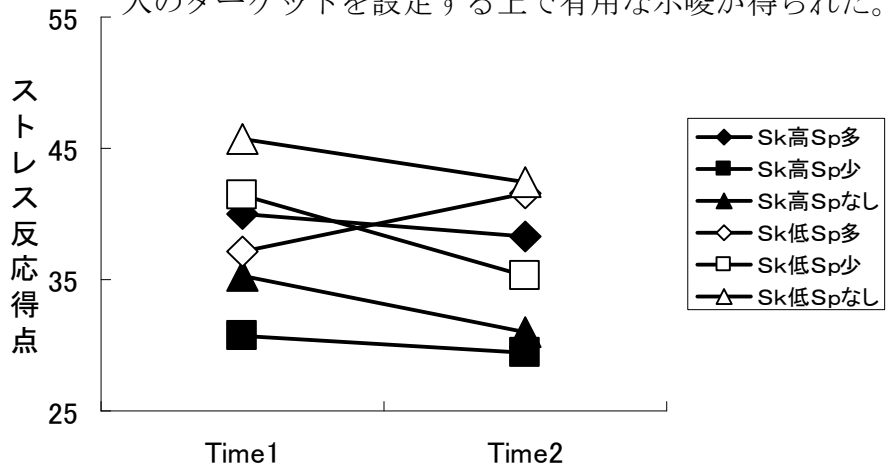

Fig 2:スキル×慰めサポート群のストレス反応の変化 